\title{
Survey of the use of warfarin and the newer anticoagulant dabigatran in patients with atrial fibrillation
}

This article was published in the following Dove Press journal:

Patient Preference and Adherence

7 February 2014

Number of times this article has been viewed

Jiyoon C Choi'

Marco d DiBonaventura ${ }^{2}$

Lewis Kopenhafer ${ }^{2}$

Winnie W Nelson ${ }^{3}$

'LifeScan, Inc, West Chester, PA, ${ }^{2}$ Health Sciences Practice, Kantar Health, New York, NY, 3Janssen Scientific Affairs LLC, Raritan, NJ, USA
Correspondence: Winnie W Nelson Janssen Scientific Affairs, LLC, 1000 US Highway 202 South, Room 3264, Raritan, NJ 08869, USA

Tel + I 9089276265

Fax + I 9089273166

Email wnelson@its.jnj.com
Background: Oral dabigatran was recently approved as an alternative to warfarin for prevention of stroke and systemic embolism in patients with nonvalvular atrial fibrillation. Unlike warfarin, dabigatran has a fixed dosage and few drug interactions, and does not require anticoagulation monitoring or dietary restrictions.

Methods: This study aimed to describe and compare characteristics of patients with atrial fibrillation who used dabigatran or only warfarin. Patients with a self-reported diagnosis of atrial fibrillation aged $\geq 18$ years who were receiving (or had received) warfarin or dabigatran completed an online survey. Differences in characteristics of dabigatran and warfarin users were tested using chi-squared tests and analysis of variance for categorical and continuous variables, respectively.

Results: Overall, 364 patients were surveyed (204 warfarin users, 160 dabigatran users). The mean age was 65.1 years, and $68.7 \%$ were male. Dabigatran users were more likely than warfarin users to be female (36.9\% versus $27.0 \%$ ) and to have experienced adverse events, including gastrointestinal bleeding, in the 3 months before the survey $(21.9 \%$ versus $6.9 \% ; P<0.05)$. Both groups reported high medication adherence (dabigatran users 0.65 versus warfarin users 0.63 missed doses/month). Dabigatran users were more likely than warfarin users to discuss treatment options with their physician before beginning therapy ( $36.9 \%$ versus $24.5 \% ; P<0.05$ ) and less likely to switch anticoagulant medication $(10.7 \%$ versus $31.9 \% ; P<0.05)$. Although dabigatran users were more likely to experience adverse events, they reported greater satisfaction with anticoagulation treatment than warfarin users.

Conclusion: The efficacy and convenience reported by dabigatran users resulted in greater treatment satisfaction among dabigatran users, even though adverse events decreased it. Treatment strategies that minimize adverse events may improve treatment satisfaction and adherence among patients with atrial fibrillation.

Keywords: atrial fibrillation, warfarin, dabigatran

\section{Introduction}

Atrial fibrillation (AF) is the most common sustained cardiac arrhythmia, ${ }^{1}$ affecting approximately $4 \%$ of individuals aged $>60$ years in the US. ${ }^{2}$ It is estimated that between 2.3 and 5.1 million people in the US are affected by AF, and, as the population ages, its prevalence is expected to increase to approximately 16 million people by $2050 .^{3}$ Thromboembolic stroke is a serious and potentially fatal consequence of AF, and patients with AF have a six-fold higher risk of stroke than those without AF. ${ }^{1}$

Anticoagulant therapy is an effective strategy for preventing stroke in patients with $\mathrm{AF}^{4-7}$ For more than 60 years, the vitamin $\mathrm{K}$ antagonist warfarin has been the mainstay of anticoagulation therapy, ${ }^{4}$ and until recently, it has been the only orally 
administered anticoagulant available in the US. Warfarin is effective in preventing stroke in patients with nonvalvular AF, but is associated with many limitations, ${ }^{8}$ including numerous food-drug and drug-drug interactions, a narrow therapeutic range, and the need for frequent anticoagulation monitoring and dose adjustment. ${ }^{8}$

In the US, alternative oral anticoagulants that are target-specific (eg, a direct thrombin inhibitor and factor $\mathrm{Xa}$ inhibitors) have been available to patients with nonvalvular AF since $2010,{ }^{9}$ when the direct thrombin inhibitor dabigatran was approved by the US Food and Drug Administration for the prevention of stroke and systemic embolism in these individuals. ${ }^{10}$ Unlike warfarin, dabigatran has a fixed, twicedaily dosing regimen and few drug-drug interactions, and does not require anticoagulation monitoring. ${ }^{4}$ Other targetspecific oral anticoagulants (TSOACs), including the factor $\mathrm{Xa}$ inhibitors rivaroxaban and apixaban, have since been approved for the prevention of stroke in patients with AF. ${ }^{11,12}$ However, when this study was conducted, dabigatran was the only oral alternative to warfarin.

The objective of this study was to describe and compare the characteristics (demographics, treatment characteristics, satisfaction, and medication adherence) of patients with AF who were currently using or had used only warfarin for anticoagulation, and of AF patients who had used the newer anticoagulant dabigatran at some point, with or without historical or current warfarin use. Given that there are limited real-world data on patient characteristics, usage patterns, medication perceptions, and treatment satisfaction since the advent of the newer anticoagulants, this survey provides a unique snapshot of early dabigatran users and their experiences while on treatment.

\section{Materials and methods Patients}

A cross-sectional survey of 364 patients with AF was conducted via the Internet from September 2011 to November 2011. Patients were recruited from either the National Health and Wellness Survey $(n=248)$ or the Lightspeed Research Internet panel $(n=31)$. Separately, 85 patients were recruited from various cities via telephone databases of patients with AF to complete the same online survey. These 85 patients were invited via emails sent to them after their recruitment.

The National Health and Wellness Survey is a selfadministered, Internet-based patient-reported questionnaire from a nationwide sample of adults aged $\geq 18$ years in the US. Lightspeed Research provides global, online market research services, with specialty panels in various areas, such as health. Due to the specific inclusion and exclusion criteria of this study, these sources of data were exhausted before the required sample size was reached. To reach the target sample size, an additional 85 respondents were recruited from databases held by research recruiters in eleven cities throughout the US. All patients who met the criteria were stratified by sex, age, and race/ethnicity to represent the demographic composition of the adult AF population in the US.

Eligible patients were aged $\geq 18$ years, had self-reported AF diagnosed by a health care provider, did not have a heart valve problem, and had used warfarin or the newer anticoagulant dabigatran as stroke prophylaxis.

All eligible patients were divided into two groups defined by current and/or prior use of dabigatran and warfarin. The "warfarin user" group comprised patients who were using only warfarin currently or had used only warfarin in the past. "Dabigatran users" were those who had ever used dabigatran, currently or in the past, including those who were currently using or had used warfarin, currently used neither dabigatran nor warfarin, or currently used both dabigatran and warfarin for anticoagulation. In this analysis, the warfarin users were compared with the dabigatran users.

\section{Outcome measures}

Differences between warfarin users and dabigatran users were examined with respect to demographics, patient characteristics, AF history, the impact of AF, symptoms of AF, knowledge and perceptions of stroke, treatment decisions, treatment characteristics, discontinuation and switching behavior, medication adherence, incidence of dyspepsia, and caregiving needs.

Statistical comparisons were tested using the chi-squared test for categorical variables and the $t$-test for continuous variables. The statistical software used was the Statistical Package for the Social Sciences version 19 (SPSS Inc, Chicago, IL, USA).

The dyspepsia survey questions were based on the ShortForm Leeds Dyspepsia Questionnaire, which was modified to include only questions relevant to physiologic areas affected by dabigatran. ${ }^{13}$ Illustrations depicting the areas affected by dyspepsia are shown in Figure 1.

The study protocol and questionnaire were reviewed and approved by the Essex Institutional Review Board. Written consent was given by all participants for their information to be stored in the study database and to be used for research.

\section{Results}

\section{Patient disposition}

A total of $364 \mathrm{AF}$ patients from the three different sources were surveyed during September 2011 to November 2011. 


\begin{tabular}{|c|c|c|c|c|c|c|}
\hline & $\begin{array}{l}\text { How often have you had this } \\
\text { symptom over the last } 3 \text { months? }\end{array}$ & Not at all & $\begin{array}{l}\text { Less than } \\
\text { once a } \\
\text { month }\end{array}$ & $\begin{array}{c}\text { Between } \\
\text { once a } \\
\text { month and } \\
\text { once a } \\
\text { week }\end{array}$ & $\begin{array}{l}\text { Between } \\
\text { once a } \\
\text { week and } \\
\text { once a day }\end{array}$ & $\begin{array}{c}\text { Once a day } \\
\text { or more }\end{array}$ \\
\hline 1 & $\begin{array}{l}\text { Indigestion } \\
\text { Indigestion is a } \\
\text { pain or discomfort } \\
\text { in the upper } \\
\text { abdomen }\end{array}$ & 1 & 2 & 3 & 4 & 5 \\
\hline 2 & $\begin{array}{l}\text { Heartburn } \\
\text { Heartburn is a } \\
\text { burning feeling } \\
\text { behind the } \\
\text { breastbone }\end{array}$ & 1 & 2 & 3 & 4 & 5 \\
\hline 3 & $\begin{array}{l}\text { Regurgitation } \\
\text { Regurgitation is an acid taste coming up } \\
\text { into your mouth from your stomach }\end{array}$ & $p$ & 2 & 3 & 4 & 5 \\
\hline 4 & $\begin{array}{l}\text { Nausea } \\
\text { Nausea is a feeling of sickness without } \\
\text { actually being sick }\end{array}$ & 1 & 2 & 3 & 4 & 5 \\
\hline 5 & Upset stomach or stomach pain & 1 & 2 & 3 & 4 & 5 \\
\hline
\end{tabular}

Figure I Dyspepsia questionnaire.

Of these patients, 204 were warfarin users and 160 were dabigatran users. The majority of patients with AF were male (68.7\%) and non-Hispanic white (91.2\%), with a mean age of 65.1 years (Table 1). Mean duration since AF diagnosis was 7.1 years, and daily pill burden was 6.26 pills. Nearly half of the patients were college-educated $(48.9 \%)$, nearly half were obese ( $44.0 \%$ body mass index $\geq 30)$, and more than half $(58.0 \%)$ had a Charlson Comorbidity Index $\geq 1$.

Analysis groups and patient cohorts are shown in Figure 2. Of warfarin users, 141 patients (69.1\%) were currently using warfarin; in the dabigatran group, 57 patients $(36 \%)$ were currently using dabigatran. Among the dabigatran users, $61(38.1 \%)$ patients had never used warfarin and had only ever used dabigatran, while 99 patients $(61.9 \%)$ had used warfarin before using dabigatran. Of warfarin users, 63 patients (31\%) had discontinued warfarin; in the dabigatran group, four patients $(5.0 \%)$ had discontinued dabigatran. Among dabigatran users, eight patients $(5.0 \%)$ who had used dabigatran were currently using warfarin, and 85 patients (53\%) who had used warfarin were currently using dabigatran. The number of patients who had used both warfarin and dabigatran but were currently using neither was six $(3.8 \%)$, while no patients were using both anticoagulants.

\section{Demographic comparison of dabigatran users versus warfarin users}

Dabigatran users were more likely to be female $(36.9 \%$ versus $27.0 \% ; P<0.05$ ), younger (60.9 years versus
68.4 years; $P<0.05)$, diagnosed with AF more recently (5.8 years versus 8.1 years; $P<0.05$ ), and to be better educated compared with warfarin users $(P<0.05$; Table 1). Levels of obesity and Charlson Comorbidity Index $\geq 1$ were significantly lower among dabigatran users $(31.9 \%$ and $51.9 \%$, respectively; $P<0.05)$ versus warfarin users $(53.4 \%$ and $62.7 \%$, respectively; $P<0.05$ ). Overall, dabigatran users took fewer types of medication on a regular basis for all medical conditions compared with warfarin users (5.3 versus 7.0; $P<0.05)$. Compared with dabigatran users, warfarin users had been receiving the current medication for a much longer (mean \pm standard deviation) length of time $(0.9 \pm 1.94$ years versus $6.3 \pm 6.15$ years; $P<0.001)$.

\section{Physical symptoms, including gastrointestinal symptoms}

Dabigatran users were significantly more likely to experience heart palpitations, irregular heartbeat, dizziness, and chest discomfort than warfarin users (Table 2). Stomach pain, nausea, regurgitation, heartburn, and indigestion were also reported more frequently in dabigatran users compared with warfarin users (Table 2).

Dabigatran users experienced significantly more gastrointestinal bleeding in the 3 months before the survey compared with warfarin users $(21.9 \%$ versus $6.9 \% ; P<0.05$; Figure $3 \mathrm{~A})$. Of patients who reported gastrointestinal bleeding in the 3 months before the survey, dabigatran users were more likely to report mild bleeding ( $85.7 \%$ versus $50 \%$; Figure $3 \mathrm{~B}$ ) 
Table I Patient demographics

\begin{tabular}{|c|c|c|c|c|c|}
\hline & \multicolumn{2}{|c|}{ Warfarin users $(n=204)$} & \multicolumn{2}{|c|}{ Dabigatran users $(n=\mid 60)$} & \multirow[t]{2}{*}{$P$-value } \\
\hline & $\%$ & $\mathbf{n}$ & $\%$ & $\mathbf{n}$ & \\
\hline \multicolumn{6}{|l|}{ Sex } \\
\hline Male & $73^{a}$ & 149 & $63^{\mathrm{a}}$ & 101 & 0.043 \\
\hline \multicolumn{6}{|l|}{ Health insurance } \\
\hline Yes & 96 & 195 & 98 & 156 & 0.329 \\
\hline \multicolumn{6}{|l|}{ Education } \\
\hline High school graduate or equivalent (eg, GED) & 16 & 32 & 13 & 21 & 0.028 \\
\hline College graduate (eg, BA, AB, BS) & 20 & 41 & 23 & 37 & \\
\hline Completed graduate school (eg, MS, MD, PhD) & 16 & 33 & 23 & 37 & \\
\hline Declined to answer & $0^{a}$ & 0 & $0.6^{\mathrm{a}}$ & 1 & \\
\hline \multicolumn{6}{|l|}{ Ethnicity } \\
\hline African American & 3 & 7 & 4 & 6 & 0.167 \\
\hline American Indian & $\mathrm{l}^{\mathrm{a}}$ & 2 & $0^{\mathrm{a}}$ & 0 & \\
\hline Asian & $3^{a}$ & 5 & $0^{\mathrm{a}}$ & 0 & \\
\hline Hispanic & 2 & 4 & 4 & 6 & \\
\hline White & 91 & 186 & 91 & 146 & \\
\hline Multiethnic & $0^{a}$ & 0 & $0.6^{\mathrm{a}}$ & I & \\
\hline Declined to answer & $0^{\mathrm{a}}$ & 0 & $0.6^{\mathrm{a}}$ & I & \\
\hline \multicolumn{6}{|l|}{ Marital status } \\
\hline Married & 66 & 135 & 68 & 108 & $0.48 \mathrm{I}$ \\
\hline Single, never married & 5 & 11 & 8 & 12 & \\
\hline Divorced & 12 & 25 & II & 17 & \\
\hline Separated & 0.5 & I & 3 & 4 & \\
\hline Widowed & 13 & 26 & 10 & 16 & \\
\hline Living with partner & 3 & 6 & 2 & 3 & \\
\hline \multicolumn{6}{|l|}{ BMI level } \\
\hline Under 18.5 & & & & & $<0.00 \mathrm{I}$ \\
\hline 18.5 to $<25$ & 13 & 27 & 16 & 26 & \\
\hline 25 to $<30$ & $30^{\mathrm{a}}$ & 61 & $49^{a}$ & 78 & \\
\hline$\geq 30$ & $53^{a}$ & 109 & $32^{\mathrm{a}}$ & 51 & \\
\hline Declined to answer & 3 & 6 & 3 & 5 & \\
\hline \multicolumn{6}{|l|}{$\mathrm{CCl}$} \\
\hline 0 & $37^{a}$ & 76 & $48^{a}$ & 77 & 0.037 \\
\hline \multirow[t]{2}{*}{ I or more } & $63^{\mathrm{a}}$ & 128 & $52^{\mathrm{a}}$ & 83 & \\
\hline & Mean & SD & Mean & SD & $P$-value \\
\hline Age, years & 68 & 9.12 & 69 & 12 & $<0.001$ \\
\hline Years diagnosed with AF & 8 & 8.79 & 6 & 7.58 & 0.008 \\
\hline Number of pills taken daily & 7 & 3.39 & 5 & 3.59 & $<0.001$ \\
\hline 1 & 5 & 2.59 & 3 & 2.50 & $<0.00 \mathrm{I}$ \\
\hline 2 & 2 & 1.70 & 2 & 1.70 & 0.355 \\
\hline 3 & 0.21 & 0.66 & 0.19 & 0.74 & 0.743 \\
\hline$\geq 4$ & 0.17 & 1.00 & 0.06 & 0.32 & 0.120 \\
\hline As needed & 0.22 & 0.64 & 0.19 & 0.58 & 0.670 \\
\hline
\end{tabular}

Note: ${ }^{2}$ Values are significantly different at $P<0.05$ in the two-sided test of equality for column proportions and equality of means.

Abbreviations: AF, atrial fibrillation; BMI, body mass index; CCI, Charlson Comorbidity Index; SD, standard deviation; GED, General Educational Development; BA, Bachelor of Arts; AB, Artium Baccalaureus; BS, Bachelor of Science; MS, Master of Science; MD, Doctor of Medicine; PhD, Doctor of Philosophy.

and bleeding that occurred once every $2-3$ months $(68.6 \%$ versus 53.8\%; Figure 3C) compared with warfarin users. Of those who reported gastrointestinal bleeding in the 3 months before the survey, more dabigatran users reported bleeding that lasted less than one day compared with warfarin users (71.4\% versus 61.5\%; Figure 3D). Dabigatran users were significantly more likely to use an over-the-counter medication $(38.7 \%$ versus $12.1 \%)$ or concomitant prescription and over-the-counter medication $(11.3 \%$ versus $4.3 \%)$ to treat stomach-related symptoms $(P<0.001$; Figure $3 \mathrm{E})$.

\section{Medication use and adherence}

Overall, medication adherence, as reported by the patients, was very high among both dabigatran users and warfarin users, with only 0.65 and 0.63 doses missed, respectively, during the month before the survey (Table 3). Of dabigatran users, $27.5 \%$ used dabigatran once daily, which is less than the approved twice-daily dosing for the AF indication. Reasons for nonadherence were similar for both dabigatran and warfarin users. However, a change in routine $(34.9 \%$ versus $6.1 \%$, respectively; $P<0.05$ ) was more commonly cited by dabigatran 


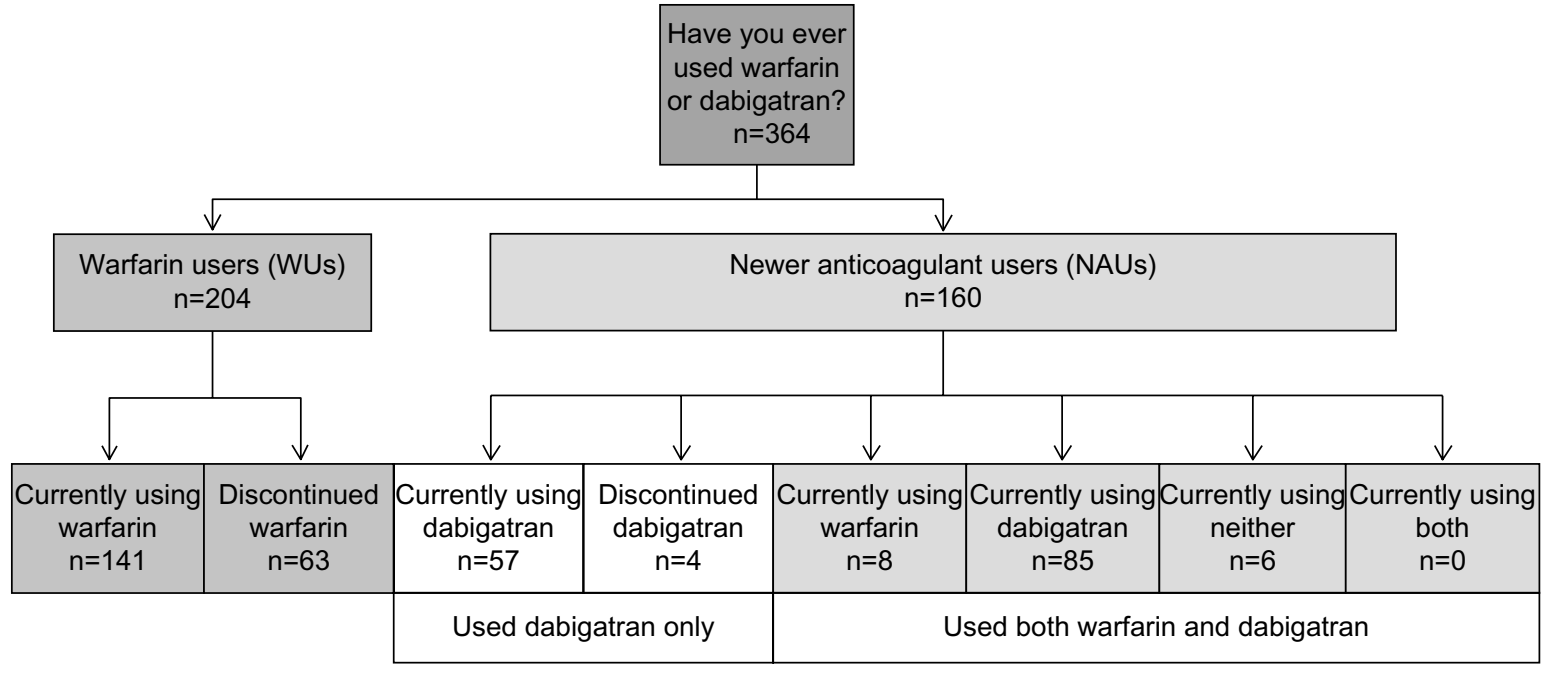

Figure 2 Analysis group definitions.

users, while risk of bleeding ( $0 \%$ versus $9.1 \%$, respectively; $P<0.05)$ was more commonly cited by warfarin users. Among dabigatran users, gastrointestinal-associated side effects were cited as a reason for nonadherence $(2 \%)$, whereas no warfarin users cited this as a reason for nonadherence.

\section{Treatment decisions and switching medication}

Dabigatran users were more likely than warfarin users to have a discussion with their physician about their treatment options before beginning anticoagulant therapy (36.9\% versus $24.5 \%$, respectively; $P<0.05)$ rather than leave the decision to their physician $(60.6 \%$ versus $73.5 \% ; P<0.05$, Table 4). Dabigatran users were significantly less likely to consider switching their medication $(10.7 \%$ versus $31.9 \%$; $P<0.05)$. Among dabigatran users who considered switching, the most common reasons were cost $(62.5 \%)$ and lack of or inadequate insurance coverage (18.8\%). In comparison, only $7.3 \%$ of warfarin users cited cost as a reason to switch from warfarin. Inconvenience factors ("too much of a hassle" [19.5\%] and "interfering with my lifestyle" [12.2\%]) were the most common reasons why warfarin users considered switching. Cost also influenced discontinuation; dabigatran users were more likely than warfarin users to discontinue treatment because of a lack of coverage by insurance ( $10 \%$ versus $0 \% ; P=0.01)$.

\section{Overall satisfaction}

Current users of warfarin or dabigatran and those who had discontinued either of these treatments were asked to indicate their level of satisfaction with their respective treatments on a scale of 1 to 7 , with 1 indicating "not at all satisfied" and 7 indicating "completely satisfied." For those who were currently taking or had ever taken dabigatran, the mean \pm standard deviation score was $5.84 \pm 0.92$, compared with a mean score of $5.26 \pm 1.57$ for those who were currently taking or had ever taken warfarin, and the difference was statistically significant $(P<0.001)$.

In addition, the survey respondents were asked to indicate whether they agreed with several statements developed to determine their attitudes toward their anticoagulant treatments. Again, a scale of 1 to 7 was used, with 1 indicating "strongly disagree" and 7 indicating "strongly agree". Compared with warfarin users, dabigatran users were significantly more confident in the ability of their medication to prevent stroke (mean score, dabigatran 5.93 \pm 1.01 versus warfarin 5.34 \pm 1.12 ; $P<0.0001$ ); dabigatran users also agreed more strongly that the benefits of dabigatran outweigh its risks (mean score, dabigatran $6.01 \pm 0.98$ versus warfarin $5.35 \pm 1.49 ; P<0.001$ ). On the other hand, warfarin users were less worried about side effects than were dabigatran users (mean score, dabigatran $4.52 \pm 1.54$ versus warfarin $4.06 \pm 1.74 ; P<0.01)$.

\section{Discussion}

The current study was conducted when TSOACs were first introduced to the US market, providing a unique snapshot of the characteristics, adherence patterns, treatment perceptions, and overall treatment experience of early TSOAC users. Despite the changing landscape of oral anticoagulation in AF patients, this study provides new data comparing treatment satisfaction of TSOAC with that of warfarin, a medication that has been the only option for several decades in the US. Our survey found that, on average, AF patients taking TSOACs were more satisfied with their 
Table 2 Incidence and frequency of symptoms

\begin{tabular}{|c|c|c|c|c|c|}
\hline & \multicolumn{2}{|c|}{ WUs $(n=204)$} & \multicolumn{2}{|c|}{ NAUs $(n=160)$} & \multirow[t]{2}{*}{ P-value } \\
\hline & $\%$ & $\mathbf{n}$ & $\%$ & $\mathbf{n}$ & \\
\hline \multicolumn{6}{|l|}{ Experienced heart palpitations } \\
\hline No & $57^{a}$ & 117 & $3 I^{a}$ & 50 & $<0.000$ I \\
\hline Yes & $43^{\mathrm{a}}$ & 87 & $69^{a}$ & 110 & \\
\hline \multicolumn{6}{|l|}{ Experienced irregular heartbeat } \\
\hline No & $4 l^{\mathrm{a}}$ & 84 & $30^{\mathrm{a}}$ & 48 & 0.028 \\
\hline Yes & $59^{a}$ & 120 & $70^{\mathrm{a}}$ & 112 & \\
\hline \multicolumn{6}{|l|}{ Experienced lack of energy } \\
\hline No & 27 & 54 & 21 & 33 & 0.194 \\
\hline Yes & 74 & 150 & 79 & 127 & \\
\hline \multicolumn{6}{|l|}{ Experienced dizziness } \\
\hline No & $5 I^{a}$ & 104 & $34^{a}$ & 55 & 0.002 \\
\hline Yes & $49^{a}$ & 100 & $66^{\mathrm{a}}$ & 105 & \\
\hline \multicolumn{6}{|l|}{ Experienced chest discomfort } \\
\hline No & $72^{\mathrm{a}}$ & 147 & $52^{\mathrm{a}}$ & 83 & $<0.0001$ \\
\hline Yes & $28^{a}$ & 57 & $48^{a}$ & 77 & \\
\hline \multicolumn{6}{|l|}{ Experienced shortness of breath } \\
\hline No & 41 & 83 & 36 & 57 & 0.325 \\
\hline Yes & 59 & $12 \mid$ & 64 & 103 & \\
\hline \multicolumn{6}{|l|}{ Overall frequency of indigestion } \\
\hline Not at all & $78^{a}$ & 159 & $44^{\mathrm{a}}$ & 70 & $<0.0001$ \\
\hline Less than once a month & $10^{\mathrm{a}}$ & 21 & $2 I^{\mathrm{a}}$ & 34 & \\
\hline Between once a month and once a week & $7^{\mathrm{a}}$ & 15 & $18^{a}$ & 28 & \\
\hline Between once a week and once a day & $3^{\mathrm{a}}$ & 5 & $14^{\mathrm{a}}$ & 23 & \\
\hline Once a day or more & 2 & 4 & 3 & 5 & \\
\hline \multicolumn{6}{|l|}{ Overall frequency of heartburn } \\
\hline Not at all & $74^{\mathrm{a}}$ & $15 \mid$ & $45^{\mathrm{a}}$ & 72 & $<0.000$ I \\
\hline Less than once a month & 14 & 29 & 16 & 26 & \\
\hline Between once a month and once a week & $6^{a}$ & 13 & $17^{a}$ & 27 & \\
\hline Between once a week and once a day & $4^{\mathrm{a}}$ & 9 & $13^{\mathrm{a}}$ & 20 & \\
\hline Once a day or more & $\mathrm{I}^{\mathrm{a}}$ & 2 & $9^{a}$ & 15 & \\
\hline \multicolumn{6}{|l|}{ Overall frequency of regurgitation } \\
\hline Not at all & $76^{\mathrm{a}}$ & 155 & $56^{\mathrm{a}}$ & 89 & $<0.0001$ \\
\hline Less than once a month & 18 & 36 & 21 & 33 & \\
\hline Between once a month and once a week & $4^{a}$ & 8 & $13^{\mathrm{a}}$ & 21 & \\
\hline Between once a week and once a day & $2^{\mathrm{a}}$ & 3 & $8^{a}$ & 13 & \\
\hline Once a day or more & 1 & 2 & 3 & 4 & \\
\hline \multicolumn{6}{|l|}{ Overall frequency of nausea } \\
\hline Not at all & $86^{\mathrm{a}}$ & 176 & $54^{\mathrm{a}}$ & 87 & $<0.0001$ \\
\hline Less than once a month & $7^{\mathrm{a}}$ & 15 & $19^{a}$ & 30 & \\
\hline Between once a month and once a week & $3^{\mathrm{a}}$ & 7 & $16^{\mathrm{a}}$ & 26 & \\
\hline Between once a week and once a day & $2^{\mathrm{a}}$ & 3 & $9^{a}$ & 14 & \\
\hline Once a day or more & 2 & 3 & 2 & 3 & \\
\hline \multicolumn{6}{|l|}{ Overall frequency of stomach pain } \\
\hline Not at all & $79^{a}$ & 162 & $49^{a}$ & 78 & $<0.000$ I \\
\hline Less than once a month & $12^{\mathrm{a}}$ & 24 & $22^{\mathrm{a}}$ & 35 & \\
\hline Between once a month and once a week & $6^{\mathrm{a}}$ & 12 & $21^{a}$ & 33 & \\
\hline Between once a week and once a day & $0.5^{\mathrm{a}}$ & 1 & $6^{\mathrm{a}}$ & 10 & \\
\hline Once a day or more & 3 & 5 & 3 & 4 & \\
\hline
\end{tabular}

Note: ${ }^{2}$ Values are significantly different at $P<0.05$ in the two-sided test of equality for column proportions and equality of means.

Abbreviations: WUs, warfarin users; NAUs, newer anticoagulant users.

therapy compared with patients taking warfarin and were significantly more confident in the ability of their medication to prevent stroke.

Our findings reflect some unique characteristics of dabigatran. We found significant differences in the incidence of heart palpitations, irregular heartbeat, dizziness, chest discomfort, and gastrointestinal bleeding between dabigatran users and warfarin users. These findings are consistent with the incidences of adverse events reported in the inaugural Randomized Evaluation of Long-term Anticoagulation 


\section{A}

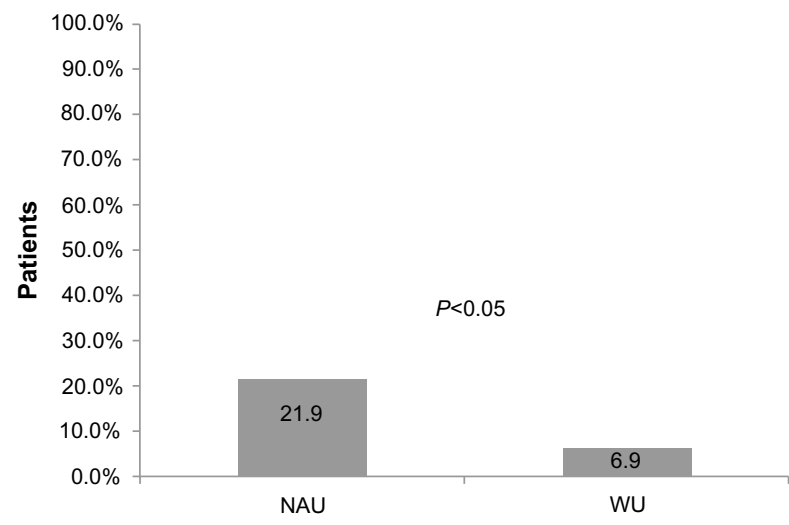

B
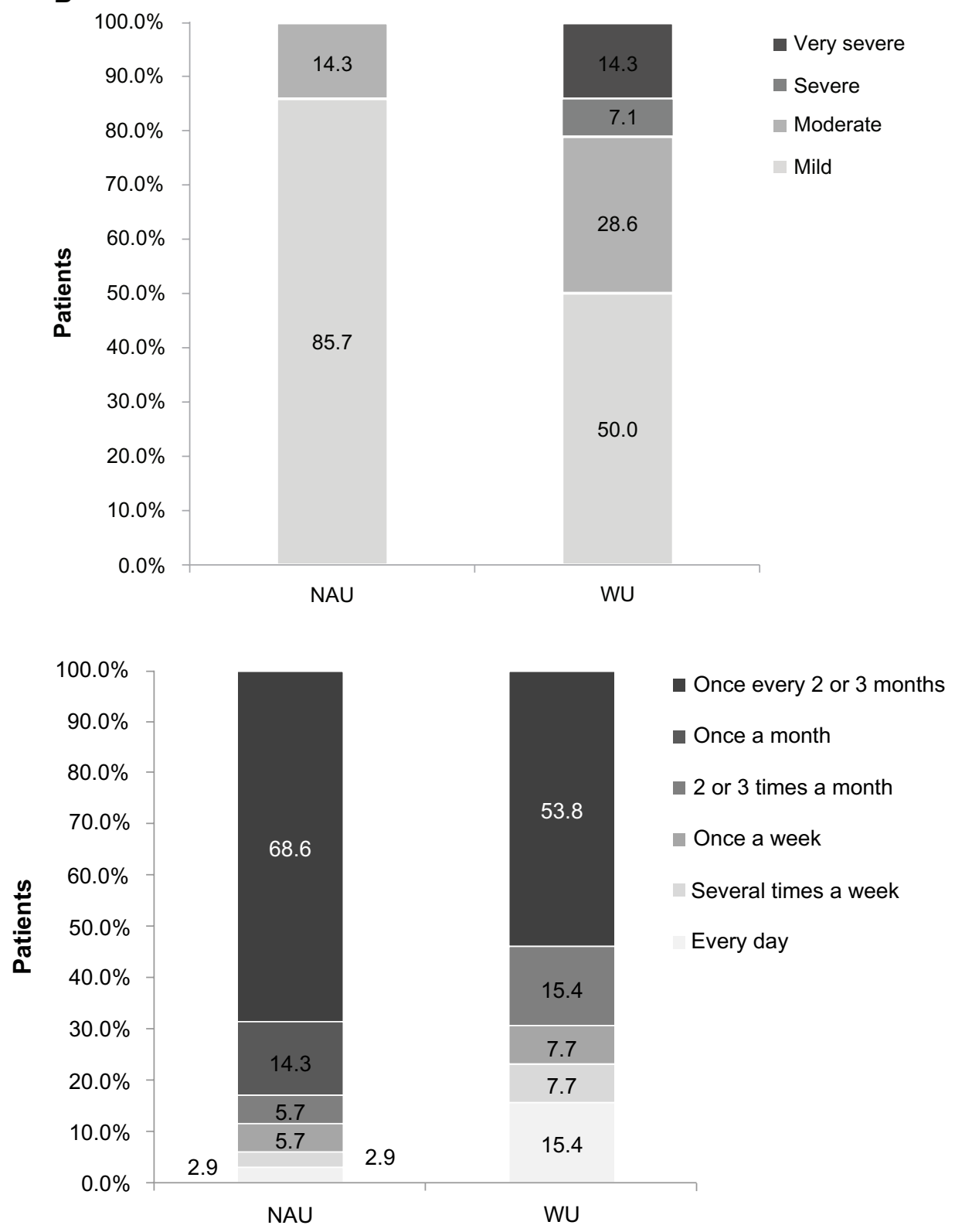

Figure 3 (Continued) 

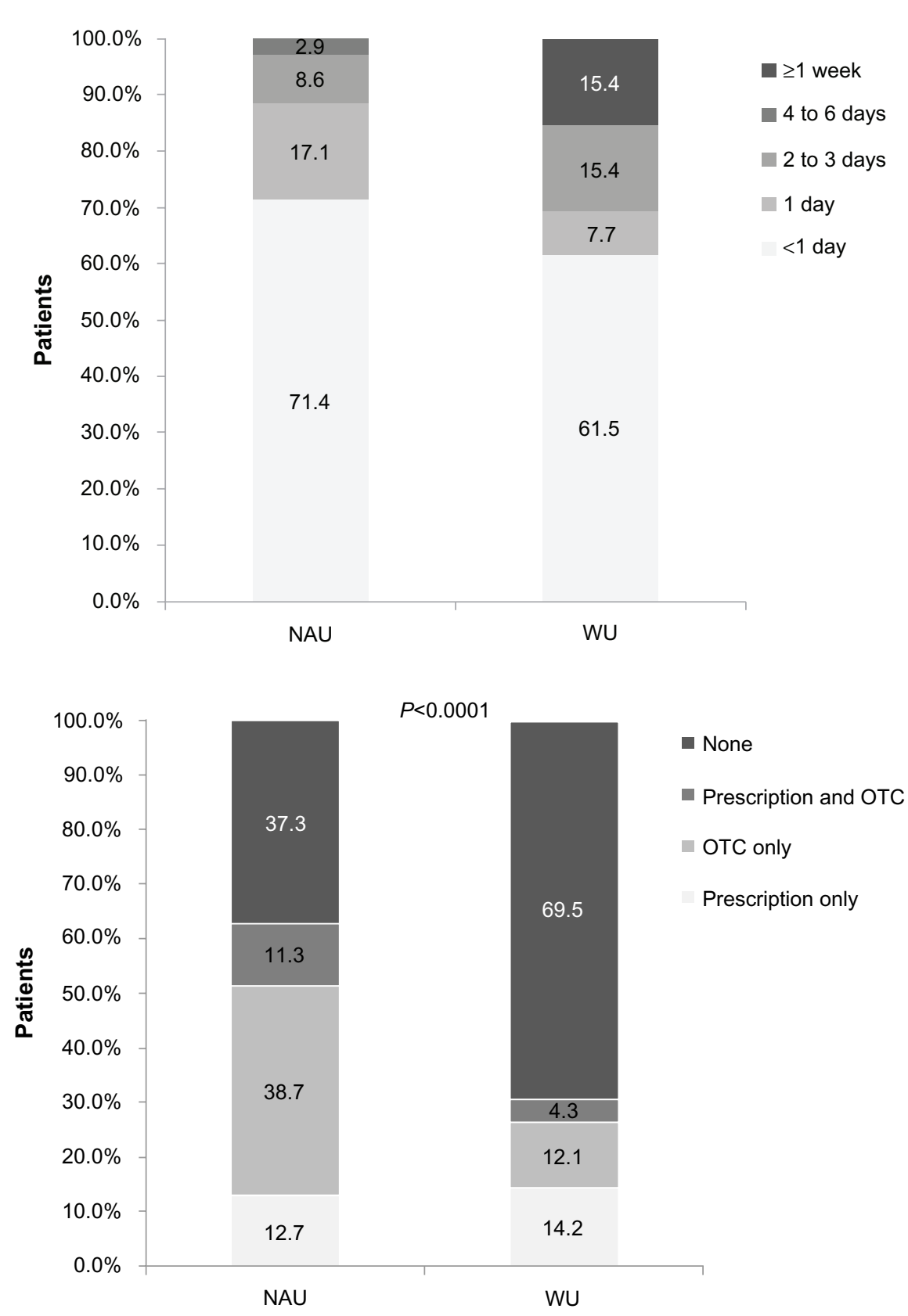

Figure 3 (A) Gastrointestinal bleeding in the 3 months before the survey, (B) severity of gastrointestinal bleeding, (C) frequency of gastrointestinal bleeding, (D) duration of gastrointestinal bleeding, and (E) use of treatments for stomach-related symptoms.

Abbreviations: WU, warfarin users; NAU, newer anticoagulant users; OTC, over the counter.

Therapy trial. ${ }^{5}$ Accordingly, patients on dabigatran were more concerned about side effects in general, stomach pain, and gastrointestinal-related side effects than were patients on warfarin.

Despite the greater incidence of adverse effects, patients still preferred dabigatran to warfarin. Overall, patients receiving dabigatran believed that the benefits of their medication outweighed the risks, and they were more likely to recommend their medication to others than were patients on warfarin. However, patients on dabigatran were much more concerned about the cost of treatment than were patients on warfarin and expressed a greater willingness to switch treatments based on higher out-of-pocket expenses compared with warfarin users. Reasons for discontinuation were similar between dabigatran users and warfarin users; however, dabigatran users were significantly more likely to discontinue because their medication was not covered by insurance.

With regard to medication adherence, there appears to be a discrepancy between the low number of doses missed per month (0.65) and the fact that $27.5 \%$ of respondents 
Table 3 Medication characteristics and adherence

\begin{tabular}{|c|c|c|c|c|c|}
\hline & \multicolumn{2}{|c|}{ Warfarin users $(n=204)$} & \multicolumn{2}{|c|}{ Dabigatran users $(n=160)$} & \multirow[t]{2}{*}{$P$-value } \\
\hline & Mean & SD & Mean & SD & \\
\hline Doses missed & 0.63 & 1.78 & 0.65 & 1.78 & 0.916 \\
\hline \multirow[t]{2}{*}{ Doses taken less than the prescribed amount } & 0.23 & 1.36 & 0.19 & 0.62 & 0.784 \\
\hline & $\%$ & $\mathbf{n}$ & $\%$ & $\mathbf{n}$ & \\
\hline \multicolumn{6}{|l|}{ Frequency of medication use per day } \\
\hline Once & $94^{a}$ & 192 & $28^{\mathrm{a}}$ & 44 & $<0.0001$ \\
\hline$\geq$ Twice & $6^{\mathrm{a}}$ & 12 & $73^{a}$ & 116 & \\
\hline \multicolumn{6}{|l|}{ I wanted to avoid the side effects of the medication } \\
\hline No & $100^{\mathrm{a}}$ & 33 & $98^{\mathrm{a}}$ & 42 & 0.378 \\
\hline Yes & $0.0^{\mathrm{a}}$ & 0 & $2^{\mathrm{a}}$ & 1 & \\
\hline \multicolumn{6}{|l|}{ I forgot to take my medication } \\
\hline No & 24 & 8 & 33 & 14 & 0.428 \\
\hline Yes & 76 & 25 & 67 & 29 & \\
\hline \multicolumn{6}{|l|}{ I didn't think my medication was working } \\
\hline No & 100 & 33 & 100 & 43 & $\mathrm{~N} / \mathrm{A}$ \\
\hline \multicolumn{6}{|l|}{ I had a change in routine } \\
\hline No & $94^{a}$ & 31 & $65^{a}$ & 28 & 0.003 \\
\hline Yes & $6^{\mathrm{a}}$ & 2 & $35^{a}$ & 15 & \\
\hline \multicolumn{6}{|l|}{ I fell asleep } \\
\hline No & 91 & 30 & 79 & 34 & 0.161 \\
\hline Yes & 9 & 3 & 21 & 9 & \\
\hline \multicolumn{6}{|l|}{ I was too busy } \\
\hline No & 91 & 30 & 84 & 36 & 0.358 \\
\hline Yes & 9 & 3 & 16 & 7 & \\
\hline \multicolumn{6}{|l|}{ It was recommended by my physician } \\
\hline No & $88^{\mathrm{a}}$ & 29 & $100^{a}$ & 43 & 0.019 \\
\hline Yes & $12^{\mathrm{a}}$ & 4 & $0^{\mathrm{a}}$ & 0 & \\
\hline \multicolumn{6}{|l|}{ I had a difficult time paying for the medication } \\
\hline No & 100 & 33 & 100 & 43 & N/A \\
\hline \multicolumn{6}{|l|}{ I ran out of medication } \\
\hline No & 97 & 32 & 93 & 40 & 0.445 \\
\hline Yes & 3 & I & 7 & 3 & \\
\hline \multicolumn{6}{|l|}{ I was concerned about interactions with alcohol } \\
\hline No & $97^{a}$ & 32 & $100^{\mathrm{a}}$ & 43 & 0.251 \\
\hline Yes & $3^{\mathrm{a}}$ & 1 & $0^{\mathrm{a}}$ & 0 & \\
\hline \multicolumn{6}{|l|}{ I was already taking too many medications } \\
\hline No & $100^{a}$ & 33 & $98^{\mathrm{a}}$ & 42 & 0.378 \\
\hline Yes & $0^{\mathrm{a}}$ & 0 & $2^{\mathrm{a}}$ & I & \\
\hline \multicolumn{6}{|c|}{ I was concerned about the risk of bleeding due to an activity I was going to do } \\
\hline No & $91^{\mathrm{a}}$ & 30 & $100^{\mathrm{a}}$ & 43 & 0.044 \\
\hline Yes & $9^{a}$ & 3 & $0^{\mathrm{a}}$ & 0 & \\
\hline \multicolumn{6}{|c|}{ I was bothered by stomach-related (gastrointestinal) side effects } \\
\hline No & $100^{\mathrm{a}}$ & 33 & $98^{\mathrm{a}}$ & 42 & 0.378 \\
\hline Yes & $0^{\mathrm{a}}$ & 0 & $2^{\mathrm{a}}$ & 1 & \\
\hline \multicolumn{6}{|c|}{ I was bothered by side effects that were not stomach-related } \\
\hline No & $97^{a}$ & 32 & $100^{a}$ & 43 & 0.251 \\
\hline Yes & $3^{\mathrm{a}}$ & I & $0^{\mathrm{a}}$ & 0 & \\
\hline \multicolumn{6}{|l|}{ Other reasons for nonadherence } \\
\hline No & 88 & 29 & 93 & 40 & 0.442 \\
\hline Yes & 12 & 4 & 7 & 3 & \\
\hline
\end{tabular}

Note: a ${ }^{V}$ alues are significantly different at $P<0.05$ in the two-sided test of equality for column proportions and equality of means.

Abbreviations: N/A, not applicable; SD, standard deviation.

reported taking their drug once daily, rather than twice daily as indicated. Survey information did not permit us to explore this, but we can speculate that patients taking even half the prescribed dose may have considered themselves to be adherent to therapy.

\section{Study limitations}

In this study, causal inference could not be drawn because of the cross-sectional study design. Also, self-reported AF diagnosed by a clinician was not verified against clinician diagnoses or chart reviews. Because this was an Internet-based 
Table 4 Treatment decisions and switching medication

\begin{tabular}{|c|c|c|c|c|c|}
\hline & \multicolumn{2}{|c|}{ WUs $(n=204)$} & \multicolumn{2}{|c|}{ NAUs $(n=160)$} & \multirow[t]{2}{*}{$P$-value } \\
\hline & $\%$ & $\mathbf{n}$ & $\%$ & $\mathbf{n}$ & \\
\hline \multicolumn{6}{|l|}{ Reason for using the current treatment } \\
\hline I made the decision myself then brought it up to my doctor & $0^{\mathrm{a}}$ & 0 & $2^{\mathrm{a}}$ & 3 & 0.018 \\
\hline A friend or family member told me to bring it up with my doctor & $0.5^{\mathrm{a}}$ & I & $0^{\mathrm{a}}$ & 0 & \\
\hline My doctor told me I needed to start taking an oral anticoagulant & $74^{a}$ & 150 & $6 I^{a}$ & 97 & \\
\hline My doctor and I discussed it, then we both agreed & $25^{\mathrm{a}}$ & 50 & $37^{\mathrm{a}}$ & 59 & \\
\hline \multicolumn{6}{|l|}{ I should start taking an oral anticoagulant } \\
\hline I don't remember & 2 & 3 & 0.6 & I & \\
\hline \multicolumn{6}{|l|}{ Have you considered switching your treatment? } \\
\hline Yes, I have seriously considered it & $9^{a}$ & 13 & $3^{\mathrm{a}}$ & 5 & $<0.00 \mathrm{I}$ \\
\hline Yes, I have somewhat considered it & $23^{a}$ & 32 & $7^{\mathrm{a}}$ & 11 & \\
\hline No, I have not considered it & $68^{\mathrm{a}}$ & 96 & $89^{a}$ & 134 & \\
\hline \multicolumn{6}{|l|}{ Reasons for switching medication } \\
\hline \multicolumn{6}{|l|}{ It does not work as well as expected } \\
\hline No & 100 & 41 & 100 & 16 & $\mathrm{~N} / \mathrm{A}$ \\
\hline \multicolumn{6}{|l|}{ It is too expensive } \\
\hline No & $93^{a}$ & 38 & $38^{\mathrm{a}}$ & 6 & $<0.0001$ \\
\hline Yes & $7^{\mathrm{a}}$ & 3 & $63^{\mathrm{a}}$ & 10 & \\
\hline \multicolumn{6}{|l|}{ It is not covered by my insurance } \\
\hline No & $100^{\mathrm{a}}$ & 41 & $8 I^{a}$ & 13 & 0.004 \\
\hline Yes & $0^{\mathrm{a}}$ & 0 & $19^{a}$ & 3 & \\
\hline \multicolumn{6}{|l|}{ It interferes with another medication I need to take } \\
\hline No & $100^{\mathrm{a}}$ & $4 I$ & $94^{a}$ & 15 & 0.106 \\
\hline Yes & $0^{\mathrm{a}}$ & 0 & $6^{a}$ & I & \\
\hline \multicolumn{6}{|l|}{ I am allergic/had an allergic reaction } \\
\hline No & 100 & 41 & 100 & 16 & $\mathrm{~N} / \mathrm{A}$ \\
\hline \multirow{2}{*}{\multicolumn{6}{|c|}{$\begin{array}{l}\text { I have experienced stomach-related/gastrointestinal side effects } \\
\text { (such as stomach pain, ulcers, blood in urine or stools) }\end{array}$}} \\
\hline & & & & & \\
\hline No & 98 & 40 & 94 & 15 & 0.482 \\
\hline Yes & 2 & I & 6 & I & \\
\hline \multicolumn{6}{|l|}{ I have experienced side effects that were not stomach-related } \\
\hline No & 93 & 38 & 88 & 14 & 0.534 \\
\hline Yes & 7 & 3 & 13 & 2 & \\
\hline \multicolumn{6}{|l|}{ I had a serious reaction/side effect } \\
\hline No & $96^{\mathrm{a}}$ & 39 & $100^{\mathrm{a}}$ & 16 & 0.368 \\
\hline Yes & $5^{a}$ & 2 & $0^{\mathrm{a}}$ & 0 & \\
\hline \multicolumn{6}{|l|}{ It is too much of a hassle to take as prescribed } \\
\hline No & 81 & 33 & 88 & 14 & 0.532 \\
\hline Yes & 20 & 8 & 13 & 2 & \\
\hline \multicolumn{6}{|l|}{ I am not able to monitor my blood as frequently as necessary } \\
\hline No & 81 & 33 & 88 & 14 & 0.532 \\
\hline Yes & 20 & 8 & 13 & 2 & \\
\hline \multicolumn{6}{|l|}{ It is interfering with my lifestyle } \\
\hline No & $88^{a}$ & 36 & $100^{\mathrm{a}}$ & 16 & 0.144 \\
\hline Yes & $12^{\mathrm{a}}$ & 5 & $0^{\mathrm{a}}$ & 0 & \\
\hline
\end{tabular}

Note: ${ }^{a}$ alues are significantly different at $P<0.05$ in the two-sided test of equality for column proportions and equality of means.

Abbreviations: WUs, warfarin users; NAUs, newer anticoagulant users.

survey, the average age of surveyed patients was younger than the average AF population. ${ }^{5}$ This could have introduced bias to the AF population, because less technologically able patients were excluded. As a result, it may not be possible to generalize the study findings to the entire AF population. Finally, the dabigatran group was necessarily heterogeneous, because of the small size of the study. A larger study would permit subgroup analysis and could yield more specific identification of factors that impact satisfaction in patients with AF. Thus, there is a need for additional and larger studies both to identify these factors and to compare the characteristics and experiences of earlier versus later dabigatran users.

\section{Conclusion}

This survey provides a comprehensive overview of the characteristics of patients with AF who are receiving warfarin 
or dabigatran for prophylaxis against stroke. It also sheds light on patients' preferences and perceptions of newer and traditional anticoagulants compared with the perspectives of early users of the TSOACs and veteran users of warfarin. This comparison is meaningful to payers and prescribers, because long-time warfarin users may be considering switching to a TSOAC.

Overall, TSOAC users experienced higher levels of treatment satisfaction compared with warfarin users, seemingly because of the increased convenience. Nevertheless, the unique side effect profile of dabigatran plays a role in the patient's experience. Patients using dabigatran were significantly more likely to experience side effects (particularly gastrointestinal symptoms) and use additional medications to treat them than were warfarin users. Although a small proportion of patients reported not taking their medications specifically because of gastrointestinal symptoms, more research is required to understand adherence patterns and predictors in this patient group. Interestingly, TSOAC users seemed to be willing to tolerate the side effects, based on their belief that the medication had high efficacy.

Our findings in this study showed that the efficacy and convenience profile of the TSOAC dabigatran increases treatment satisfaction, while the adverse events with dabigatran had the opposite effect. Treatment strategies that minimize medication side effects may improve treatment satisfaction and adherence among patients with AF. This may be the first step toward helping patients maintain adherence to their stroke prevention medications.

\section{Disclosure}

The authors acknowledge Parveena Laskar of Chameleon Communications International, who provided editorial support with funds provided by Janssen Scientific Affairs, LLC. Janssen Pharmaceuticals, Inc, is the manufacturer of rivaroxaban. The authors have no other conflicts of interest in this work.

\section{References}

1. Fuster V, Rydén LE, Cannom DS, et al; American College of Cardiology/ American Heart Association Task Force on Practice Guidelines; European Society of Cardiology Committee for Practice Guidelines; European Heart Rhythm Association; Heart Rhythm Society. ACC/AHA/ESC 2006 Guidelines for the Management of Patients with Atrial Fibrillation: a report of the American College of Cardiology/American Heart Association Task Force on Practice Guidelines and the European Society of Cardiology Committee for Practice Guidelines (Writing Committee to Revise the 2001 Guidelines for the Management of Patients With Atrial Fibrillation): developed in collaboration with the European Heart Rhythm Association and the Heart Rhythm Society. Circulation. 2006;114:e257-e354.

2. Rosenthal L. Atrial fibrillation. eMedicine (online). Available from: http://emedicine.medscape.com/article/151066-overview\#showall Accessed January 3, 2013.

3. Miyasaka Y, Barnes ME, Gersh BJ, et al. Secular trends in incidence of atrial fibrillation in Olmsted County, Minnesota, 1980 to 2000, and implications on the projections for future prevalence. Circulation. 2006;114:119-125.

4. Ansell J, Hirsh J, Hylek E, Jacobson A, Crowther M, Palareti G; American College of Chest Physicians. Pharmacology and Management of the Vitamin K Antagonists: American College of Chest Physicians Evidence-Based Clinical Practice Guidelines. 8th ed. Chest. 2008;133: 160S-198S.

5. Connolly SJ, Ezekowitz MD, Yusuf S, et al; RE-LY Steering Committee and Investigators. Dabigatran versus warfarin in patients with atrial fibrillation. $N$ Engl J Med. 2009;361:1139-1151.

6. Granger CB, Alexander JH, McMurray JJ, et al; ARISTOTLE Committees and Investigators. Apixaban versus warfarin in patients with atrial fibrillation. N Engl J Med. 2011;365:981-992.

7. Patel MR, Mahaffey KW, Garg J, et al; ROCKET AF Investigators. Rivaroxaban versus warfarin in nonvalvular atrial fibrillation. $N$ Engl J Med. 2011;365:883-891.

8. Coumadin [package insert]. Princeton, NJ, USA: Bristol Myers Squibb; 2010.

9. Hilleman DE. New oral anticoagulants for stroke prevention in atrial fibrillation. Am J Pharm Benefits 2012;4:269-283.

10. Boehringer Ingelheim. US FDA approves Pradaxa ${ }^{\mathbb{B}}$ (dabigatran etexilate)a breakthrough treatment for stroke risk reduction in non-valvular atrial fibrillation. Available from: http://www.boehringer-ingelheim.com/ news/news_releases/press_releases/2010/20_october_2010_dabigatran. html. Accessed December 24, 2012.

11. US Food and Drug Administration. FDA approves Xarelto to prevent stroke in people with common type of abnormal heart rhythm. Available from: http://www.fda.gov/NewsEvents/Newsroom/ PressAnnouncements/ucm278646.htm. Accessed December 24, 2012.

12. Warner J. FDA approves new blood thinner Eliquis. Available from: http://www.webmd.com/heart-disease/atrial-fibrillation/ news/20121231/fda-blood-thinner-eliquis. Accessed March 8, 2013.

13. Fraser A. The Short-Term Leeds Dyspepsia Questionnaire validation study. Aliment Pharmacol Ther. 2007;25:477-486.
Patient Preference and Adherence

\section{Publish your work in this journal}

Patient Preference and Adherence is an international, peer-reviewed, open access journal focusing on the growing importance of patient preference and adherence throughout the therapeutic continuum. Patient satisfaction, acceptability, quality of life, compliance, persistence and their role in developing new therapeutic modalities and compounds to

\section{Dovepress}

optimize clinical outcomes for existing disease states are major areas of interest. This journal has been accepted for indexing on PubMed Central. The manuscript management system is completely online and includes a very quick and fair peer-review system. Visit http://www.dovepress.com/ testimonials.php to read real quotes from published authors. 